\title{
ANALISIS PERAN SUKUK AL-INTIFA'A SEBAGAI INSTRUMEN DALAM MENGENTASKAN KEMISKINAN DI INDONESIA
}

\author{
Dadang Wiratama1, Bintang Ramadhan Putra2 \\ 1,2 Universitas Airlangga \\ Email; 1dadang.wiratama-2019@feb.unair.ac.id \\ 2bintang.ramadhan-2018@pasca.unair.ac.id
}

\begin{abstract}
Today the capital market is one of the instruments that plays an important role in the economy of developed and developing countries. For developing countries like Indonesia, the capital market is an economic potential that is able to offer solutions to capital problems that are often faced in the context of national development. Especially when efforts to obtain additional capital through loans are felt to be increasingly unprofitable. Likewise with the Islamic capital market, although it is still new when compared to other Islamic financial instruments, the development of the Islamic capital market in Indonesia is considered quite good. One of the sharia financial instruments that is an important financing for the state budget is sukuk. At home, sukuk are growing quite rapidly although the proportion is still relatively small compared to conventional markets. This will be able to support the development of the Islamic capital market in Indonesia, especially if it is able to capture the opportunities that exist. One such opportunity is waqf assets which are widely available in various regions in Indonesia and many are still not being worked productively. Dual integration between sukuk and waqf in Al Intifa' a Sukuk is expected to be able to create a financial instrument that can boost economic development and alternatives for poverty alleviation efforts in Indonesia.
\end{abstract}

Keyword: Sukuk, Waqf, Poverty, Islamic Capital Market

\begin{abstract}
Abstrak
Dewasa ini pasar modal menjadi salah satu instrumen yang memainkan peranan penting dalam perekonomian negara maju maupun berkembang. Bagi negara berkembang seperti Indonesia, pasar modal merupakan potensi perekonomian yang mampu menawarkan solusi bagi permasalahan permodalan yang sering dihadapi dalam rangka pembangunan nasional. Terlebih ketika upaya perolehan tambahan modal melalui pinjaman dirasa semakin tidak menguntungkan. Demikian halnya dengan pasar modal syariah, walaupun masih baru jika dibandingkan dengan instrumen keuangan syariah yang lain, tapi perkembangan pasar modal syariah di Indonesia dinilai cukup baik, Salah satu instrumen keuangan syariah yang menjadi pembiayaan penting bagi anggaran negara adalah sukuk. Di dalam negeri sendiri, sukuk tumbuh cukup pesat walaupun proporsinya masih relatih kecil dibandingkan dengan pasar konvensional. Hal ini akan mampu menunjang perkembangan pasar modal syariah di Indonesia, apalagi jika mampu menangkap peluang yang ada. Salah satu peluang tersebut adalah aset wakaf yang banyak terdapat di berbagai wilayah di Indonesia dan masih banyak yang belum tergarap secara produktif. Dual integrasi antara sukuk dan wakaf dalam Sukuk Al Intifa'a diaharapkan mampu menciptakan sebuah instrumen keuangan yang bisa mendongkrak pembangunan ekonomi dan seabgai alternatif dalam upaya pengentasan kemiskinan di Indonesia.
\end{abstract}

Website: http://jurnal.radenfatah..ac.id/index.php/ieconomics 


\section{Kata kunci : Sukuk, Waqf, Kemiskinan, Pasar Modal Syariah}

\section{PENDAHULUAN}

Fenomena bangkitnya minat yang besar terhadap industri keuangan Islam tahun-tahun belakangan ini ditunjukkan dengan muncul dan tumbuhnya bentuk sekuritis Islam (sukuk), yang memiliki kemampuan besar untuk menawarkan solusi keuangan yang inovatif. Tidak hanya produknya yang benar-benar memberi kontribusi terhadap usaha untuk melakukan inovasi prduk, tetapi juga keberadaan yang sebanding dengan pasar modal konvensional lainnya. Produk-produk antar Negara (sovereign) dipertimbangkan secara aktif oleh perusahaan penerbit alternatif baru ini, untuk kebutuhan pembiayaan dan investasi 1.

Trend pasar keuangan global menuju kearah disintermediasi. Dengan kata lain, peran pasar modal lebih dominan daripada peran sistem perbankan (financial intermediaries) dalam alokasi sumber daya keuangan. Oleh karena itu, pasar modal akan menjadi masa depan bagi perekonomian dan sistem keuangan bagi negara maju dan negara yang masuk dalam kategori emerging markets seperti Indonesia. Hal ini ditunjang dengan kehadiran sukuk pada tahun 2002 yang merupakan suatu terobosan dalam perkembangan pasar modal syariah di Indonesia karena mampu menjadi alternatif sebagai instrumen obligasi bagi perusahaanperusahaan yang memerlukan sumber dana eksternal 2.

Sebagai salah satu instrumen pembiayaan jangka panjang, sukuk dapat dikatakan sudah menjadi alternatif sebagai dana investasi dan proyek bagi pemerintah dan perusahaan. 3 Nilai sukuk pemerintah pada September 2015 berjumlah Rp.298 triliyun atau 36 kali lipat dari sukuk korporasi yang bernilai Rp 8,28 triliun. Dominasi SBSN atas sukuk korporasi sepertinya akan terus berlanjut di periode berikutnya mengingat banyaknya proyek infrastruktur yang pendanaannya berasal dari penerbitan sukuk oleh pemerintah 4 .Dilihat dari laju pertumbuhan sukuk di 2015 semakin meningkat.

\footnotetext{
1 Huda, N dan Nasution. 2008. Investasi Pada Pasar Modal Syariah. Jakarta: Kencana Media Grup. 2 MES .2015. Sharia economic outlook 2016.Jakarta, Indonesia: Masyarakat Ekonomi Syariah. 3 Azmat, Skully, \& Brown. 2014. The Shariah Compliance Challenge In Islamic Bond Market. Pasific Basin Finance Journal, 28. hal.47-57.

4 MES. 2015. Shariah economic outlokk 2016. Jakarta, Indonesia: Masyarakat Ekonomi Syariah.
}

Website: http://jurnal.radenfatah..ac.id/index.php/ieconomics 


\section{Tabel 1}

\section{Perkembangan Sukuk Korporasi}

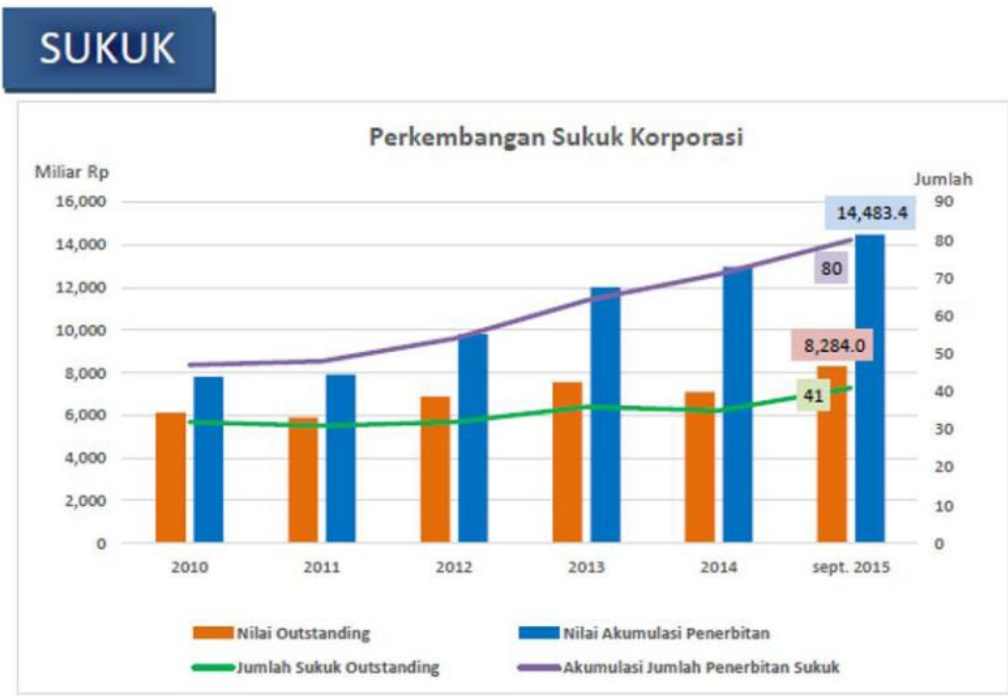

Sukuk pada hakikatnya merupakan sertifikat kepemilikan atas suatu aset yang dapat digunakan dalam skala besar untuk membiayai pembangunan karena sukuk bukanlah jual beli surat berharga di pasar sekunder, melainkan sebuah pembiayaan. Sukuk mendapat jaminan berupa jaminan aset (underlying asset) dan dijadikan sebagai dasar penerbitan sukuk yang berfungsi untuk menghindari unsur riba dan prasyarat dapat diperdagangkan sebagaimana Fatwa DSN MUI tentang ketentuan umum SBSN point 2 berbunyi "Aset SBSN adalah obyek pembiayaan SBSN dan/atau Barang Milik Negara (BMN) yang memiliki nilai ekonomis, berupa tanah dan/atau bangunan, maupun selain tanah dan/atau bangunan yang dalam rangka penerbitan SBSN dijadikan dasar penerbitan SBSN". Hal ini menjadi pedoman pada penerbitan sukuk.

Oleh karenanya, penulis menyajikan suatu konsep solusi terhadap optimalisasi sukuk berbasis aset wakaf (Sukuk Al-intifa'a) mengingat pemanfaatan aset wakaf di Indonesia belum optimal. Sebagai salah satu filantropi Islam, wakaf merupakan aset publik yang mampu dijadikan solusi negara dalam mengurangi kemiskinan dan meningkatkan kesejahteraan apabila pemanfatannya dimaksimalkan. Berdasarkan data dari Kementrian Agama Republik Indonesia, luas tanah wakaf di Indonesia pada tahun 2012 mencapai angka 3.492.045.373,754 m2 yang tersebar di 420.003 lokasi di seluruh wilayah Indonesia atau setara dengan dua kali luas Singapura. Seharusnya lahan yang bernilai triliun rupiah itu bersifat produktif. Namun, kenyataannya tanah wakaf itu belum digarap secara optimal, bahkan banyak lahan yang terbengkalai dan tidak memberikan manfaat bagi kesejahteraan masyarakat 5 .

\section{LANDASAN TEORI}

5 Rozalinda. 2015. Manajemen Wakaf Produktif. Penerbit: Rajawali.

Website: http://jurnal.radenfatah..ac.id/index.php/ieconomics 
Esensi wakaf adalah bahwa ia menyediakan dukungan kepada orang miskin yang membutuhkan secara berkelanjutan serta sebagai kontributor utama dalam konsep lamanya dan tidak dapat dicabut6. Sisi yang belum direalisasi secara berlanjutan adalah kemampuan aset wakaf untuk menghasilkan atau menumbuhkan pendapatan atau modal. Keduanya signifikan untuk saat ini. Oleh karena itu, upaya keberlanjutan diperlukan untuk memperbesar ruang lingkup pendapatan dari aset wakaf.7 Dalam penelitian (Furqon, 2016) 8 yang berjudul "Model-model Pembiayaan Wakaf Tanah Produktif" menemukan bahwa banyak model pembiayaan yang dapat diterapakan bagi pembiayaan tanah waqaf, akan tetapi, pembiayaan yang mengurangi resiko kerugian perlu menjadi pertimbanagn lembaga dalam memilih model pembiayaan tersebut.

Dalam penelitian Syairozi, tahun 20169 ditemukan bahwa dual integrasi antara sukuk dan waqaf dalam sukuk Al-intifa'a diharapkan mampu menciptakan sebuah instrument keuangan yang bisa memaksimalkan produktifitas sektor pasar modal syariah dan sektor wakaf. Sedangkan dalam penelitian yang dilakukan Lastuti, 201710 regulasi sukuk di Indonesia masih bersifat parsial dan tersebar aturan sehingga mengakibatkan rendahnya pemahaman pelaku usaha dan investor terhadap kerangka hukum sukuk serta jaminan kepastian hukum.

Adapan model investasi yang dapat digunakan untuk pengelolaan wakaf produktif dapat berupa investasi langsung pada sektor riil maupun instrumen moneter. Di mana keseluruhan peluang investasi sangat fleksibel untuk diterapkan di Indonesia. Bahkan dalam sebuah penelitian, hal ini sangat menguntungkan bagi lembaga pengelola wakaf untuk mengoptimalkan fungsi investasinya11. Ciri disunahkannya wakaf dalam Islam adalah semua bentuknya sangat potensial untuk dikembangkan terutama sebagai aset wakaf produktif. Bahkan juga memberikan analisis bahwa harta wakaf cenderung untuk selalu cenderung setiap masa dan untuk mejaga keberlangsungan wakaf menurutnya adalah dengan menyisihkan harta benda wakaf yang produktif dari umat Islam untuk kesejahteraan umat dan bagian dari kepekaan beragama.

Pemberdayaan wakaf seperti itu, dengan sendirinya akan menciptakan lapangan kerja baru, citra Islam akan semakin positif, mengubah posisi dari "tangan di bawah menjadi tangan di atas" dan keuntungan sosial lainnya. Oleh sebab itu sudah saatnyalah para nadzir wakaf berpikir keras untuk dapat memberdayakan tanah-tanah wakaf yang bernilai ekonomis tinggi dalam rangka menggapai tujuan itu sendiri yaitu penekanan akan arti pentingnya kemanfaatan bagi umat manusia. Singkatnya, wakaf menjadi solusi bagi pengembangan harta

\footnotetext{
6 Stibbard, P., Russell, D., \& Bromley, B. (2012). Understanding the waqf in the world of the trust. Trusts \& Trustees, 18(8), 785-810. https://doi.org/10.1093/tandt/tts087

7 Azrai Azaimi Ambrose, A. H., Gulam Hassan, M. A., \& Hanafi, H. (2018). A proposed model for waqf financing public goods and mixed public goods in Malaysia. International Journal of Islamic and Middle Eastern Finance and Management. https://doi.org/10.1108/IMEFM-01-2017-0001.

8 Furqon. 2014. Model-Model Pembiayaan Wakaf Tanah Produktif. Economica: Jurnal Ekonomi Islam, 5(1), 1. https://doi.org/10.21580/economica.2014.5.1.760

9 M Imam Syairozi and Septyan Budy Cahya. 2016. 'Sukuk Al Intifa'a: Integrasi Sukuk Dan Wakaf Dalam Meningkatkan Produktifitas Sektor Wakaf Pendorong Investasi Pada Pasar Modal Syariah', II.2 (2016), 386-97. 10 Lastuti Abubakar and Tri Handayani. 2017. 'Kesiapan Infrastruktur Hukum Dalam Penerbitan Sukuk (Surat Berharga Syariah) Sebagai Instrumen Pembiayaan Dan Investasi Untuk Mendorong Pertumbuhan Pasar Modal Syariah Indonesia', Jurnal Jurisprudence, 7.1 (2017), 1-14 <https://doi.org/10.23917/jurisprudence.v7i1.4348>. 11 Ai Nur Bayinah. 2012. 'Exploring and Empowering Waqf Invesment Toward an Acceleration of Economic', Conference Proceedings Annual Internasional Conference on Islamic Studies (AOCIS XI), 2012, 2681-2707.
}

Website: http://jurnal.radenfatah..ac.id/index.php/ieconomics 
produktif di tengahtengah masyarakat dan solusi dari kerakusan pribadi dan kesewenangwenangan pemerintah secara bersamaan 12 .

\section{METODE PENELITIAN}

Metode yang digunakan dalam artikel ini adalah metode eksploratif yang dilaksanakan melalui pendekatan studi literatur tentang sukuk berbasis wakaf, sukuk al-intifa serta menggali kajian-kajian dari penelitian sebelumnya tentang bagaimana mengoptimalisasikan wakaf melalui sukuk. Sehingga diharapkan paper ini dapat lebih memberikan acuan implementasi pengoptimalisasian sukuk berbasis wakaf di Indonesia dalam upaya mengentaskan kemiskinan.

\section{PEMBAHASAN}

\section{Aplikasi Sukuk Dalam Pasar}

Sukuk bentuk jamak dari kata 'sakk' digunakan oleh masyarakat muslim pada abad pertengahan sebagai 'kertas' yang mewakili kewajiban yang berasal dari aktifitas perdagangan dan aktivitas komersial lainnya (Saputra, 2007:227). Berdasarkan fatwa DSNMUI No.32/DSN-MUI/IX/2002: surat berharga syariah adalah surat berharga jangka panjang berdasarkan prinsip syariah yang dikeluarkan oleh emiten kepada pemegang sukuk berupa bagi hasil/fee/margin serta membayar kembali dana obligasi pada saat jatuh tempo. Accounting and Auditing Organisation for Islamic Finance Institutions (AAOIFI) mendefinisikan "sukuk sebagai sertifikat dari suatu nilai yang direpresentasikan setelah penutupan pendaftaran, bukti terima nilai sertifikat dan menggunakanya sesuai rencana, sama halnya dengan bagian dan kepemilikan atas aset yang tangible, barang atau jasa atau modal dari suatu proyek tertentu atau modal dari suatu aktivitas investasi tertentu" (Saputra, 2007:228).

Pada gambar 1 dibawah ini dapat menjelaskan alur dimana obligasi dapat memberikan kontribusi pada kestabilan ekonomi suatu Negara. Sebagai contoh, Indonesia mengekspor barang keluar negeri, dan dari ekspor tersebut mendapatkan penghasilan berupa devisa dalam US dolar. Mata uang ini tentunya tidak dapat digunakna secara langsung di pasar barang maupun uang di Indonesia, sehingga perlu ditukarkan ke dalam rupiah di pasar valas maupun ke bank sentral. Selanjutnya pelaku di pasar valuta asing menukarkan sejumlah mata uang asing ke bank sentral dengan mata uang domestik. Dengan kondisi dimana mata uang domestik. Dengan kondisi dimana mata uang asing lebih dominan di pasar uang maupun barang domestik, kemungkinan bagi bank sentral untuk memenuhi kebutuhan masyarakat akan mata uang domestik semakin terbatas, mengingat cadangan devisa yang terbatas pula. Selain itu, dengan semakin banyaknya jumlah uang yang beredar mengindikasikan tingkat konsumerisme yang tinggi dalam masyarakat, yang tentunya akan berimplikasi kepada tingkat inflasi yang tinggi. Oleh karena itu, bank sentral dalam upayanya untuk menyerap dana-dana di masyarakat sehubungan dengan masalah-masalah moneter,

12 Azman Ab Rahman, Mohammad Haji Alias, and Syed Mohd Najib Syed Omar. 2014. 'Zakat Institution in Malaysia: Problems and Issues', Global Journal Al-Thaqafah, <https://doi.org/10.7187/GJAT122012.02.01>.

Website: http://jurnal.radenfatah..ac.id/index.php/ieconomics 
maka bank sentral menerbitkan obligasi yang dapat dimiliki oleh masyarakat, baik secara individu maupun lembaga (Jusmaliani, 2008:357-358).

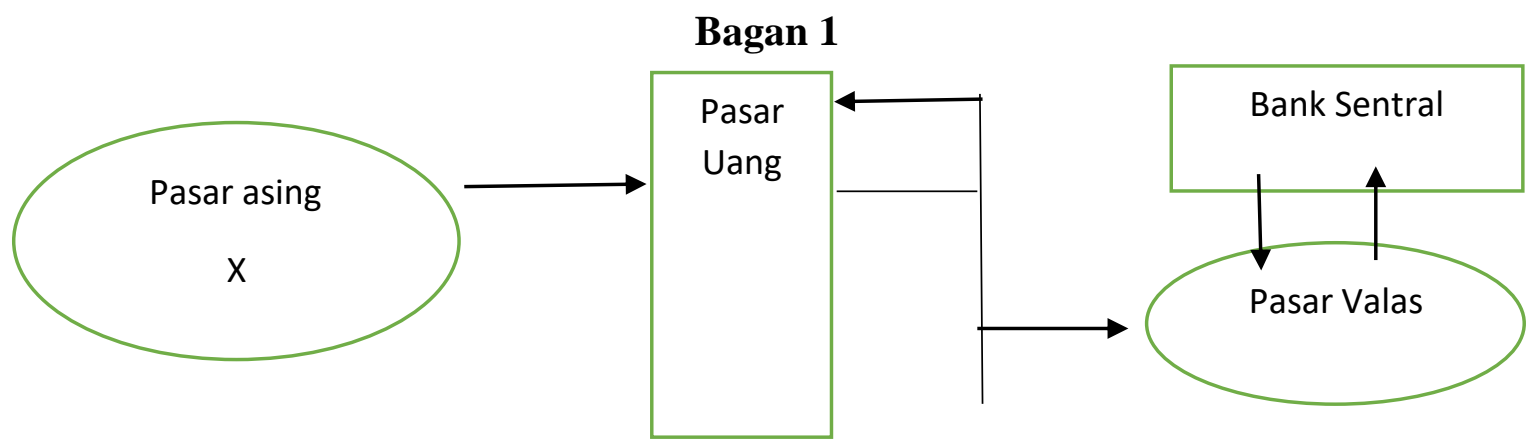

AAOIFI, dalam standar syariah mengenai sukuk investasi, membahas jenis-jenis sertifikat investasi atau sukuk, diantaranya (Ayyub, 2007: 396):

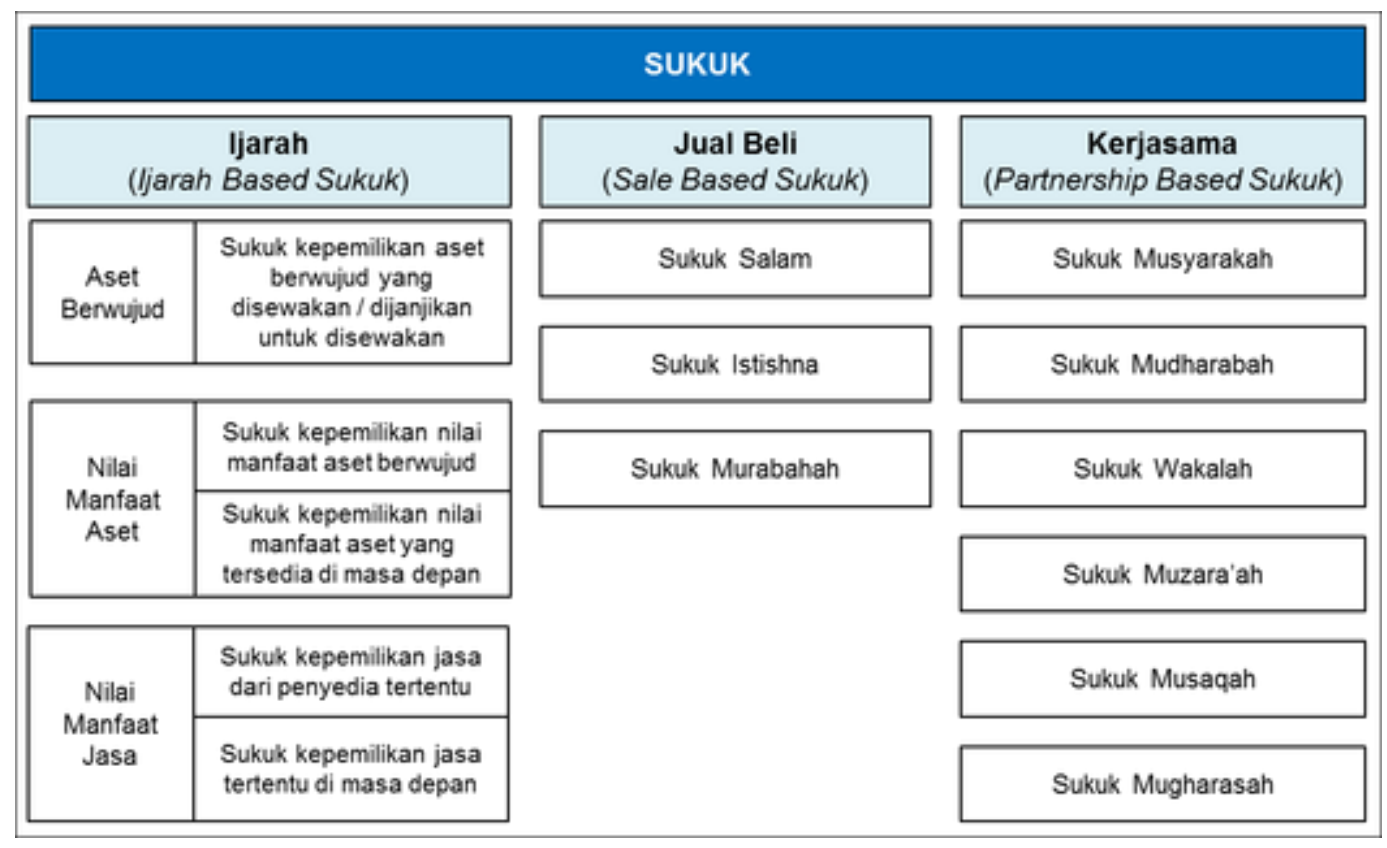

Adapun dari berbagai jenis sukuk tersebut, jenis kontrak yang memiliki potensi yang paling besar yaitu sertifikat investasi yang berbasiskan syirkah, ijarah, salam dan istisna'. Berdasarkan peraturan dasar syariah, sukuk investasi tersebut harus berada pada dasar yang aturan yang satu dan terintegrasi agar mampu memenuhi prinsip syariah. Karena jika, ada banyak pihak yang mengatur atau menetapkan aturan tersebut, tentu sukuk tersebut tidak mempunyai arah yang jelas.Tingkat keuntungan sukuk akan selalu bervariatif, tergantung dengan jenis kontrak yang dipilih dan hasil dari investasi yang dijalankan. Untuk sukuk dengan penghasilan tetap dapat dilakukan jika adanya pihak ketiga sebagai penjamin, dalam hal ini kontrak yang digunakan merupakan kontrak kepastian.Penerbit atau pemegang sukuk dapat mengadopsi metode apapun yang diperbolehkan dalam penanganan dan pengurangan risiko, seperti dengan cara menciptakan dana takaful dengan kontribusi dari pemegang sertifikat atau mencari perlindungan dari perusahaan takaful dan membayar kontribusi dari pendapatan pada saat penerbitan atau sumbangan dari pemegang sukuk. Diperbolehkan juga untuk mengesampingkan sejumlah presentase keuntungan guna mengurangi fluktuasi dari 
keuntungan yang akan didistribusikan, asalkan pengungkapan yang sepantasnya dilakukan dalam prospektus penerbitan.

\section{Skema Sukuk Ijarah Berbasis Waqaf}

Kontrak ijarah telah dibenarkan oleh Al-Quran, Sunnah, ijma ulama dan 'urf. Ulama mazhab juga telah mengkajinya secara mendalam hingga akhirnya mereka tidak menemukan sesuatu yang bertentangan dengan syara'. Bahkan, bentuk kontrak ini lebih lanjut dapat dikembangkan dalam sistem pembiayaan modern seperti pasar modal. Kontrak ijarah yang dikembangkan dalam bentuk pasar modal lebih dikenal dengan ijarah sukuk. Ia adalah sertifikat sukuk yang dikeluarkan berdasarkan aset-aset tertentu yang sah mempunyai nilai ekonomis, terdiri dari petak tanah, bangunan, dan barang-barang lain yang masuk dalam aset yang berharga (Wahid, 2010:117). Bentuk sukuk ijarah ini terdiri dari (a) tangible assets, di mana investor memiliki bagian dari aset dan pendapatan yang berhubungan dengan ijarah, (b) kepentingan yang bermanfaat bagi investor mendapatkan hak sewa atas aset yang dengan kontrak sukuk dapat memperoleh manfaat al-ijarah.

Ijarah memiliki fleksibilitas yang tinggi dan potensi yang besar untuk penerbitan sukuk, tapi beberapa karakteristik penerbitan sukuk ijarah atau kesepakatan yang terlibat dalam prosesnya merupakan petunjuk bagi permasalahan berbeda yang terkait dengan syariah. Berdasarkan peraturan syariah, pemegang sukuk harus secara bersama - sama menanggung risiko dari harga aset dan biaya yang terkait dengan kepemilikannya dan membagi uang sewanya dengan menyewakannya kepada siapa pun. Kemungkinan biaya tak terduga yang terkait dengan kepemilikan aset relevan yang disewakan dan kemungkinan terjadinya kegagalan, tingkat keuntungannya hanya bisa menyerupai tetap dan bukan tetap secara absolut atau tidak dapat diubah jika ditetapkan untuk mengikuti tolak ukur tertentu. Namun, tingkat keuntungan sebagian besar sukuk adalah tetap secara absolut dan tidak dapat dimodifikasi. Aspek ini mengandung risiko sistemik yang tidak sesuai dengan syariah serta membuat hal paling mendasar dari sistem financial Islami tidak sah dan bertentangan dengan aspirasi investor yang berdasarkan pada keyaikinan mereka.

Pada sukuk ijarah berbasis wakaf, sekurang-kurangnya ada empat pihak yang terlibat yaitu (1) Badan Wakaf Indonesia (BWI) atau nadzir, (2) developer, (3) the special porpose vehicle (SPV) sebagai penerbit ijarah sukuk, dan (4) investor. Pembangunan terhadap harta wakaf secara komersial ini dilaksanakan di atas sebidang tanah wakaf yang dikelola oleh BWI/nadzir dengan menggunakan kaidah atau konsep Build Operate and Transfer (BOT) melalui penerbitan sukuk al-intifa' yang berasaskan kepada akad ijarah mawsufah fi zimmah (Omar \& Ab Rahman, 2013). Kemudian akan disewakan kepada investor sebagai pengguna manfaat dengan akad kontrak ijarah mawsufah fi zimmah. Ijarah mawsufah fi zimmah adalah sewa aset yang belum tersedia atau dimiliki oleh lessor, pada saat perjanjian. Perjanjian tersebut, bagaimanapun, didasarkan pada usaha oleh lessor untuk memberikan aset berdasarkan setuju spesifikasi rinci, nilai dan waktu ketersediaan. Sewa pembayaran di bawah ijarah ini merupakan hak lessee untuk menggunakan properti di masa depan setiap kali properti siap untuk digunakan.

Sukuk al-intifa' adalah instrumen yang layak untuk membiayai wakaf investasi. Di samping merupakan suatu kepatuhan syariah karena didasarkan pada kontrak ijarah, sukuk alintifa' memiliki beberapa karakteristik yang menjadikannya sebagai instrumen keuangan yang menguntungkan. Karakteristiknya adalah sebagai berikut (Kholid, Sukmana, \& Hassan, 2009): 
Sekuritisasi sewa: pemegang sukuk akan memiliki manfaat dari penggunaan aset yang disewakan kepada pihak lain (yang terakhir ini tentu saja pemegang akan menerima pembayaran rutin).

2 . sukuk mampu menjual (tradable) kepihak lain (di Pasar sekunder) ketika ia membutuhkan uang tunai mendesak.

3.

Durasi sukuk yang dapat berubah-ubah; durasi aset yang disewakan dapat diubah atau dibagi menjadi beberapa periode sewa. Fleksibilitas durasi memberikan manajemen arus kas yang lebih baik institusi wakaf.

4 . berikutnya.

Transfer Opsional sukuk yang tepat untuk tahun

\section{Bagan 2 \\ Bentuk penerbitan sukuk Ijarah berbasis wakaf}

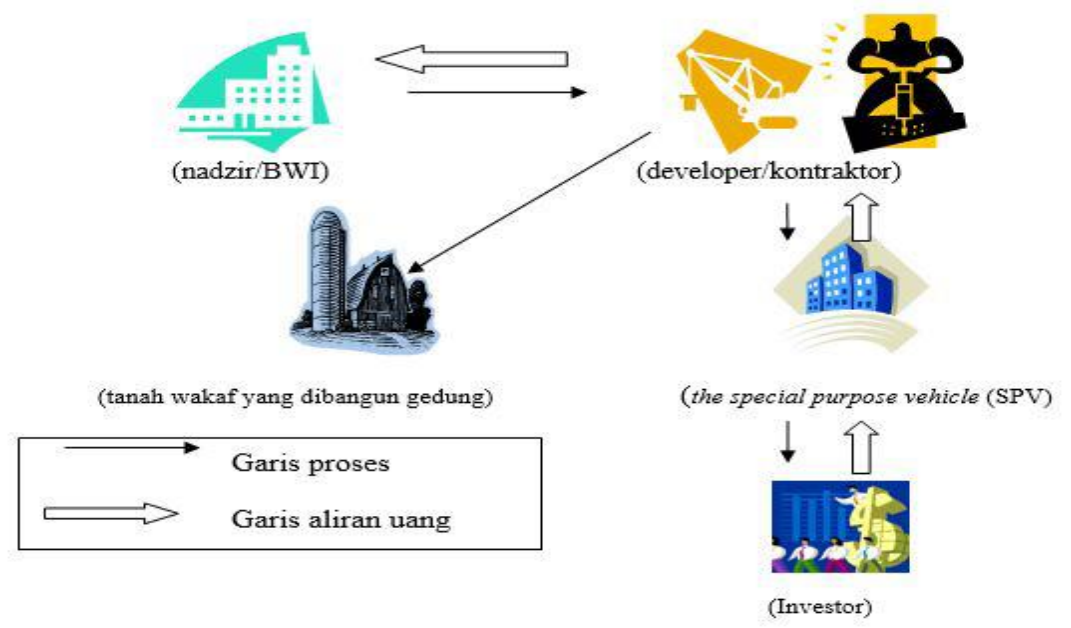

Keterangan:

1.

Nadzir/BWI/pengelola wakaf menyewakan tanah wakaf yang dikelolanya kepada pihak developer yang tertarik dengan menggunakan kaidah/konsep BOT. Biaya sewa yang disepakati, yang harus dibayarkan developer dalam bentuk gedung, bukan uang tunai.

2 . tanah wakaf

b.

3.

4. sukuk al-intifa' dengan menggunakan kontrak ijarah.

5 . membayar setiap bulan atau setiap tahun kepada SPV sampai waktu yang ditetapkan. 6. 7.

a. Developer membangun gedung yang diperlukan diatas

Developer membayar pajak atas tanah wakaf Pihak developer menyewakan aset kepada SPV.

SPV memproses pengeluaran sukuk dan mengeluarkan

Investor bersedia menyewa aset tersebut, kemudian SPV membayar harga aset kepada developer.

Pihak developer berkewajiban memberikan gedung kepada nadzir sebagai biaya sewa atas tanah wakaf yang dikelolanya sampai jatuh tempo. 
Sistem pembayaran tidak dilakukan setiap bulan atau setiap tahun, melainkan secara penuh setelah berakhir masa sewa.

\section{Karakteristik Sukuk Linked Waqaf}

Produk sukuk linked wakaf merupakan bentuk penggabungan dua cakupan dalam keuangan Islam, yaitu komersil dan sosial. Hal ini menjadi unik dibanding produk keuangan konvensional sehingga menjadi alternatif baru bagi dunia keuangan Islam di Indonesia. Pasar investor yang dituju memiliki karakteristik khusus, yaitu memiliki motivasi keuntungan atas investasi dan didasari pula pada motivasi sosial untuk pengembangan aset wakaf di Indonesia. Hal ini diharapkan dapat menjadi solusi atas dua permasalahan di atas, yaitu dapat mengoptimalkan tanah wakaf sekaligus memperdalam pasar keuangan syariah khususnya pada sektor pasar modal.

Proses penerbitan sukuk linked wakaf akan melibatkan beberapa pihak, setidaknya terdiri dari Badan Wakaf Indonesia (BWI), Perusahaan BUMN, SPV, dan investor. Pada tahap awal, BWI akan melakukan perjanjian jangka panjang kepada BUMN dengan kontrak pengelolaan tanah wakaf selama jangka waktu tertentu. Selanjutnya, BUMN menyerahkan proposal proyek kepada Special Purpose Vehicle (SPV) lalu diterbitkanlah sukuk BUMN dengan akad tertentu, -penulis akan menguraikan produk ini dengan menggunakan akad musyarakah mutanaqisah.

Tahap selanjutnya, pihak BUMN menyerahkan proposal proyek kepada Special Purpose Vehicle (SPV) lalu diterbitkanlah sukuk korporasi dengan akad musyarakah mutanaqisah (diminishing musyarakah). Tanah wakaf dijadikan underlying asset penerbitan sukuk tersebut. Model sukuk ini menggunakan akad musyarakah mutanaqisah untuk menghindari pemindahan kepemilikan dari obligor kepada investor. Dengan asumsi menggunakan jenis sukuk asset backed, akad ini tetap memisahkan kepemilikan aset sebagai modal antara pihak obligor dan investor. Obligor (BUMN) tetap memiliki proporsi kepemilikan penuh atas tanah wakaf, sedangkan investor memiliki proporsi kepemilikan atas gedung yang dibangun dengan modal mereka. Akad ini juga bertujuan untuk mendapatkan kepemilikan aset secara penuh (tanah dan gedung) dengan cara menyicil kepada investor sehingga kepemilikan investor terhadap gedung semakin menurun (diminishing) dan dalam jangka waktu yang ditentukan keseluruhan aset akan dimiliki penuh oleh obligor.

Return proyek musyarakah ini diperoleh dari penyewaan gedung kepada tenant yang dibangun di atas tanah wakaf. Selanjutnya, bagi hasil dibagikan kepada pihak investor dan obligor sesuai dengan kesepakatan diawal, sedangkan kerugian harus dapat ditanggung sesuai dengan proporsi modal. Dengan proyek penyewaan gedung, risiko yang dihasilkan tidak terlalu besar dan cenderung menghasilkan return tetap dan dapat diprediksi. Obligor secara berkala menggunakan sebagian keuntungannya untuk membeli sebagian kepemilikan investor. Hingga pada akhir jatuh tempo, obligor dapat memiliki keseluruhan aset dan dapat menyerahkannya kembali kepada nadzir. Setelah tanah wakaf dan aset proyek dikembalikan, return yang dihasilkan dari tanah wakaf tentu akan menjadi lebih besar karena telah dikelola dengan produktif.

Salah satu negara yang telah mempraktikan produk serupa adalah Arab Saudi dengan mendirikan Zam-Zam Tower. Bangunan ini berdiri di atas lahan yang diwakafkan oleh Raja Arab Saudi di bawah pengelolaan King Abdul Aziz Waqf (KAAW) yang bertindak sebagai nazhir. KAAW menyewakan kepada konglomerasi Binladin Group dengan sistem konsensi 
yang disebut BOT (Build-Operate-Transfer) dalam jangka waktu 28 tahun. Kemudian, Binladin Group mensubkontrakkan konsesinya kepada Munshaat, sebuah perusahaan properti asal Kuwait. Sehingga Munshaat memiliki kewajiban mengembalikan pengelolaan gedung Zam-Zam Tower kepada KAAW sebagai nazhir wakaf. Pembiayaan megaproyek ini senilai US\$390.000.000 ini dilakukan oleh Munshaat dengan menerbitkan sukuk Intifa'a dengan jangka waktu 24 tahun.

\section{Sukuk Linked Waqaf Untuk Mengentaskan Kemiskinan di Indonesia}

\section{Bagian 3}

\section{Proses Sukuk Negara Linked Waqaf}

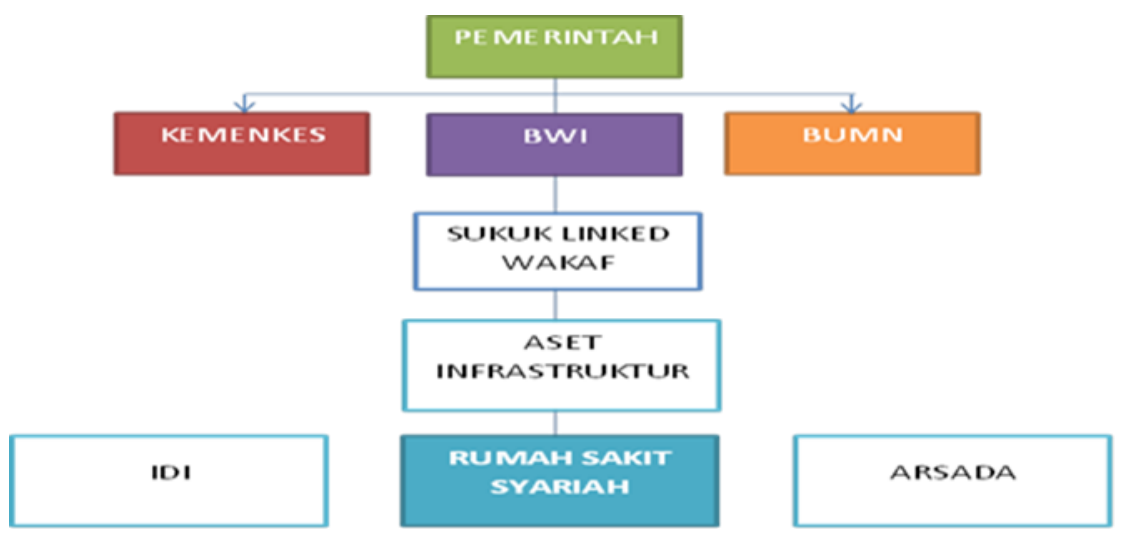

Wakaf produktif melalui Sukuk Negara dilandasi keinginan untuk mensinergikan potensi wakaf temporer yang dimiliki oleh masyarakat Indonesia baik secara langsung maupun melalui berbagai lembaga ZISWAF (zakat, infaq, shodaqoh dan waqaf) dengan penggunaan proceed (hasil penerbitan) Sukuk Negara untuk keperluan pembangunan. Sinergi tersebut diharapkan memberikan dampak besar dalam mendorong pembangunan serta mengirangi kemiskinan dengan memanfaatkan dana imbal hasil dari Sukuk Negara.

Sederhananya, alur Wakaf Produktif melalui Sukuk Negara, yaitu: masyarakat Indonesia melalui beberapa badan ZISWAF (selaku pihak yang berwakaf atau wakif) membeli Sukuk Negara dalam tenor tertentu. Selanjutnya dibuat perjanjian bahwa investor Sukuk Negara (selaku Wakif) tidak menerima imbalan dari Sukuk Negara. Imbalan selama tenor Sukuk Negara disalurkan kepada badan ZISWAF yang disepakati untuk digunakan dalam berbagai program pengurangan kemiskinan. Setelah tenor Sukuk Negara berakhir (jatuh tempo) maka dana investasi dari para Wakif akan diterima kembali secara otomatis. Dengan demikian, wakaf produktif melalui Sukuk Negara ini dapat dikategorikan sebagai wakaf temporer selama tenor Sukuk, sedangkan hasil investasinya disedekahkan untuk program pengurangan kemiskinan.

Pemerintah, melalui Peraturan Menteri Keuangan Nomor 75/PMK.08/2009 tentang Penerbitan dan Penjualan SBSN dengan Cara Penempatan Langsung (Private Placement), memberikan kesempatan kepada perorangan WNI maupun kumpulan perorangan (organisasi/non organisasi) di dalam maupun di luar negeri untuk berinvestasi pada Sukuk Negara secara penempatan langsung. Hal ini dilakukan melalui peserta lelang yang ditunjuk Pemerintah. Sesuai aturan, investasi langsung melalui Sukuk Negara minimal Rp. 250 miliar atau US\$100 juta. Dengan demikian, kesempatan berpartisipasi dalam program wakaf 
produktif melalui Sukuk Negara sebenarnya terbuka luas bagi masyarakat perorangan dan badan amal termasuk Dewan Kemakmuran Masjid (DKM).

Dalam pemanfaatan dana imbalan Sukuk Negara untuk penanggulangan kemiskinan, lembaga/badan ZISWAF selaku penerima dana perlu berkoordinasi dengan antar lembaga ZISWAF maupun Pemerintah agar program tidak tumpang tindih. Program ini tentu akan lebih baik apabila dilakukan secara reguler dengan jumlah yang terprediksi sehingga kedepannya dapat ditentukan sasaran yang ingin dicapai. Misalnya, dalam satu tahun investasi wakaf produktif ini ditargetkan untuk mengentaskan 10 ribu orang dari jurang kemiskinan. Dengan koordinasi yang baik, transparansi dalam pemanfaatan dana, dan hasil yang nyata, diharapkan semakin banyak masyarakat Indonesia berperan serta dalam wakaf produktif ini serta semakin banyak menciptakan muwaqif baru.

\section{SIMPULAN}

Sukuk memberikan potensi yang luar biasa besar untuk pertumbuhan dalam pasar global modal Islami yang sangat penting bagi perkembangan terus menerus industri keuangan Islami. Kemunculannya telah menarik minat banyak orang dalam pembiayaan proyek sektor publik dan swasta yang mencakup infrastruktur, seperti jalan, jembatan, pelabuhan, bandar udara dan sebagainya.

Penciptaan Sukuk yang memenuhi Syariat Islam seperti Ijarah dapat dijadikan basis untuk meningkatkan kerjasama di antara negara-negara Muslim dan pasar finansial dengan memanfaatkan aset wakaf. Pada sukuk ijarah berbasis wakaf sekurang-kurangnya ada empat pihak yang terlibat yaitu (1) Badan Wakaf Indonesia (BWI) atau nadzir, (2) developer, (3) the special porpose vehicle (SPV) sebagai penerbit ijarah sukuk, dan (4) investor. Pembangunan terhadap harta wakaf secara komersial ini dilaksanakan di atas sebidang tanah wakaf yang dikelola oleh BWI/nadzir dengan menggunakan kaedah atau konsep build, operate and transfer (BOT) melalui penerbitan sukuk al-intifa'. Kemudian akan disewakan kepada investor sebagai pengguna manfaat dengan akad kontrak Ijarah mawsufah fi Zimmah.

\section{DAFTAR PUSTAKA}

(MES), Masyarakat Ekonomi Syariah, Sharia Economic Outlook 2016 (Jakarta, Indonesia: Masyarakat Ekonomi Syariah., 2015)

Ab Rahman, Azman, Mohammad Haji Alias, and Syed Mohd Najib Syed Omar, 'Zakat Institution in Malaysia: Problems and Issues', Global Journal Al-Thaqafah, 2012 <https://doi.org/10.7187/GJAT122012.02.01>

Abubakar, Lastuti, and Tri Handayani, 'Kesiapan Infrastruktur Hukum Dalam Penerbitan Sukuk (Surat Berharga Syariah) Sebagai Instrumen Pembiayaan Dan Investasi Untuk Mendorong Pertumbuhan Pasar Modal Syariah Indonesia', Jurnal Jurisprudence, 7.1 (2017), 1-14 <https://doi.org/10.23917/jurisprudence.v7i1.4348>

Azmat, Saad, Michael Skully, and Kym Brown, 'The Shariah Compliance Challenge in Islamic Bond Markets', Pacific Basin Finance Journal, 28 (2014), 47-57 <https://doi.org/10.1016/j.pacfin.2013.11.003> 
I-Economic: A Research Journal on Islamic Economics

ISSN 2548-5601, e-ISSN 2548-561X

Vol 6. No 1. Juni 2020

Furqon, Ahmad, 'Model-Model Pembiayaan Wakaf Tanah Produktif', Economica: Jurnal Ekonomi Islam, 5.1 (2016), 1 <https://doi.org/10.21580/economica.2014.5.1.760>

Huda, N dan Nasution, M.E., Investasi Pada Pasar Modal Syariah (Jakarta: Kencana Prenada Media Group, 2008)

M.Ag., Dr. Rozalinda, Manajemen Wakaf Produktif (Rajawali Pers, 2015)

Nur Bayinah, Ai, 'Exploring and Empowering Waqf Invesment Toward an Acceleration of Economic', Conference Proceedings Annual Internasional Conference on Islamic Studies (AOCIS XI), 2012, 2681-2707

Qohaf, Mundzir, Manajemen Wakaf Produktif (Jakarta: Penerbit Khalifa, 2005)

Rozalinda. 2015. Manajemen Wakaf Produktif. Penerbit : Rajawali.

Syairozi, M Imam, and Septyan Budy Cahya, 'Sukuk Al Intifa'a: Integrasi Sukuk Dan Wakaf Dalam Meningkatkan Produktifitas Sektor Wakaf Pendorong Investasi Pada Pasar Modal Syariah', II.2 (2016), 386-97 